\title{
PENGEMBANGAN BAHAN AJAR KOMIK PADA MATA PELAJARAN BAHASA INDONESIA MATERI PERJUANGAN PARA PAHLAWAN
}

\author{
Yustiorini, Ma'as Shobirin, Ersila Devy Rinjani \\ Program Studi Pendidikan Guru Madrasah Ibtidaiyah \\ Fakultas Agama Islam Universitas Wahid Hasyim Semarang \\ yustiorini@gmail.com
}

\begin{abstract}
Abstrak
Pengembangan bahan ajar pada mata pelajaran bahasa Indonesia ini menjadi salah satu upaya dalam meningkatkan mutu pendidikan di sekolah. Basis cerita bergambar/komik pada bahan ajar yang dikembangkan menjadi salah satu pilihan yang sesuai bagi peserta didik dan pengajar untuk lebih mendalami materi dengan motivasi yang tinggi karena bentuknya yang berbeda dari yang sudah ada. Metode penelitian yang digunakan dalam penelitian ini adalah Research and Development ( R\&D) dengan menggunakan model yang dikembangkan oleh Borg and Gall. Hasil skor keefektifan diperoleh dari hasil belajar. Hasil skor keefektifan bahan ajar komik menunjukkan 89,81 \%. Hasil perhitungan diperoleh pada $\alpha=5 \%$ dengan $\mathrm{dk}=22-1=21$ diperoleh ttabel $=2,119$. Didapat thitung $=$ $11,054 \geq$ ttabel $=2,119$ karena thitung $\geq$ ttabel maka hipotesis (Ha) diterima. Proses pembelajaran dapat disimpulkan ada peningkatan hasil belajar sesudah siswa menggunakan bahan ajar komik dan karena hal tersebut bahan ajar dikatakan efektif.
\end{abstract}

Kata kunci: Pengembangan, bahan ajar komik, bahasa Indonesia

\begin{abstract}
The development of teaching materials in Bahasa Indonesia lesson is one of efforts to improve education quality in schools. Basic of illustrated story/comic on teaching materials is developed become an appropriate choice for students and teachers to explore more material with high motivation because of its different form from the existing ones. The research method used in this study is Research and Development (R\&D) using a model developed by Borg and Gall. The results of the effectiveness score were obtained from learning outcomes. The score for the effectiveness of comic teaching materials was $89.81 \%$. The calculation results obtained at $\alpha=5 \%$ with $d k=22-1=21$ obtained t table $=$ 2.119. Obtained $t$ count $=11,054 \geq t$ table $=2.119$ because $t$ count $\geq t$ table then the hypothesis (Ha) is accepted. The learning process can be concluded that there is an increase in learning outcomes after students use comic teaching materials and because of this the teaching materials are said effective.
\end{abstract}

Keywords: Development, comic as teaching materials, Bahasa Indonesia 


\section{A. PENDAHULUAN}

Pendidikan merupakan suatu hal yang sangat penting dan tidak dapat dipisahkan dari kehidupan seseorang baik dalam keluarga, masyarakat dan bangsa. Negara Indonesia sebagai negara berkembang membutuhkan sumber daya manusia yang berkualitas. Salah satu usaha menciptakan sumber daya manusia yang berkualitas adalah melalui pendidikan. Sekolah sebagai salah satu lembaga pendidikan formal memiliki peranan yang sangat penting dalam mewujudkan tujuan pendidikan nasional melalui proses belajar mengajar. Peningkatan kualitas sumber daya manusia merupakan salah satu penekanan dari tujuan pendidikan, seperti yang tertuang dalam Undang-Undang No. 20 Tahun 2003 tentang tujuan Pendidikan Nasional Bab III Pasal 3 yang berbunyi:

"Pendidikan Nasional bertujuan mengembangkan kemampuan dan membentuk watak serta peradaban bangsa yang bermartabat dalam rangka mencerdaskan bangsa, bertujuan untuk berkembangnya potensi peserta didik agar menjadi manusia yang beriman dan bertakwa kepada Tuhan YME, berakhlak mulia, sehat, berilmu, cakap, kreatif, mandiri dan menjadi warga negara yang demokratis serta bertanggung jawab". ${ }^{1}$

Pembelajaran Bahasa Indonesia merupakan pembelajaran yang tidak akan pernah lepas dari empat keterampilan yakni keterampilam membaca, keterampilan mendengar, keterampilan menulis dan keterampilan berbicara. Pada dasarnya pembelajaran bahasa Indonesia bertujuan untuk membentuk dan mengembangkan keterampilan komunikasi pada siswa, baik berupa lisan maupun tulisan. Adapun dalam pembelajaran tulisan siswa dilatih untuk mengungkapkan suatu gagasan dan mengembangkan kosa kata lewat sebuah karangan dengan berlandaskan pada pengetahuan, pengalaman serta ide imajinatif. Untuk menumbuhkan kreativitas siswa dalam mencurahkan pemikirannya lewat sebuah bacaan, dibutuhkan sebuah keterampilan untuk membaca dengan baik agar tidak mudah bosan.

Salah satu keterampilan menulis yang harus dipelajari anak sejak usia dini yakni keterampilan menulis dan memahami sastra. Sastra merupakan sesuatu yang menarik yang dapat memberikan hiburan, mampu memupuk dan menanam rasa keindahan. ${ }^{2}$ Banyak anak di jaman sekarang tidak begitu memahami apa itu sastra,

3.

${ }^{1}$ Undang- Undang RI, Tentang Sistem Pendidikan Nasional, No. 20 Tahun 2003, Bab III Pasal

2 Burhan Nurgiyantoro, Sastra Anak Pengantar Pemahaman dunia anak, Yogyakarta: Gadjah Mada University Press, 2010, hlm. 100 
padahal dalam pembelajaran bahasa Indonesia yang dicantumkan dalam kurikulum, siswa harus mencapai tujuan dalam pembelajaran diarahkan untuk mencapai beberapa tujuan yang harus dimiliki salah satunya yakni kesadaran diri atas pentingnya karya sastra bagi pengembangan diri dan sikap positif siswa terhadap karya sastra. ${ }^{3}$ Dengan adanya pembelajaran sastra di sekolah dasar yang ditanamkan sejak dini dapat menjadikan titik masuk pendidikan karakter pada anak. ${ }^{4}$ Disamping itu juga siswa bisa menikmati dan memanfaatkan karya sastra untuk memperluas wawasan serta meningkatkan pengetahuan dan kemampuan berbahasa dan dengan pembelajaran sastra siswa bisa menanamkan budi pekerti baik dan mudah memahami sebuah kehidupan dari pengalaman orang lain.

Setiap bidang pelajaran mempunyai materi untuk diajarkan. Setiap materi ajar memiliki banyak isi yang perlu disampaikan dengan teliti dan efektif agar pembelajaran menjadi sebuah kegiatan yang menyenangkan untuk dijalankan dengan tidak memisahkan keseriusan dalam pelaksanaan pembelajaran di kelas. Salah satu upaya menyampaikan materi ajar di kelas adalah dengan menggunakan bahan ajar sebagai acuan materi yang disampaikan.

Dewasa ini pembelajaran bahasa Indonesia hanya terpatok literasi atau membaca buku materi, membaca buku sebanyak-banyaknya dengan kurang dilandasinya pemahaman isi dari bacaan tersebut. Sering kita jumpai setelah selesai membaca tidak faham apa yang dibaca, alasan inilah yang menjadikan siswa, terkadang, sering lupa akan inti materi yang disampaikan. Beberapa masalah yang mungkin timbul ialah dalam wujud kesulitan memahami tulisan ilmiah, kata-kata ganda, dan kata-kata sambung.

Untuk mengurangi hal tersebut, peneliti berupaya mengembangkan sebuah bahan ajar yang berisi tentang materi beserta pemahaman berupa cerita bergambar guna memudahkan siswa dan guru dalam mempelajari dan menyampaikan materi perjuangan para Pahlawan. Bahan ajar berbasis cerita bergambar ini dikembangkan sesuai dengan penelitian yang dilakukan agar buku yang dihasilkan sesuai dengan yang dibutuhkan oleh siswa pada saat ini.

3 Yunus Abidin, Pembelajaran Bahasa Berbasis Pendidikan Karakter, Bandung: PT. Refika Aditama, 2012, hlm. 17

${ }^{4}$ Zulela, Pembelajaran Bahasa Indonesia Apresiasi Sastra di Sekolah Dasar, Bandung: PT. Remaja Rosdakarya, 2013, hlm. 13 
Seperti yang ditulis oleh Ika Lestari di dalam bukunya yang memuat tentang bahan ajar yakni, pada prinsipnya, semua buku dapat dijadikan sebagai bahan belajar bagi siswa, hanya saja yang membedakan bahan ajar dari buku lainnya adalah cara penyusunannya karena didasarkan atas kebutuhan pembelajaran yang diinginkan siswa dan belum dikuasai dengan baik. ${ }^{5}$ Hal ini membuktikan bahwa bahan ajar memiliki kelebihan dibandingkan dengan buku pelajaran lain pada umumnya. Adapun basis cerita komik di dalam bahan ajar adalah untuk menambah motivasi belajar siswa dan motivasi mengajar guru. Dalam suatu kutipan dari lansiran berita dinyatakan, Mantan Mentri Pendidikan Nasional Mohammad Nuh mengatakan ide dasar komik buku pelajaran ini berawal dari keinginan untuk memberikan buku pelajaran yang menarik sehingga materi pelajaran yang terkesan sulit akan menjadi mudah karena disuguhkan dalam bentuk komik atau gambar. ${ }^{6}$

Pengembangan bahan ajar pada mata pelajaran bahasa Indonesia ini menjadi salah satu upaya dalam meningkatkan mutu pendidikan di sekolah. Dengan basis cerita bergambar/komik, bahan ajar yang dikembangkan akan menjadi salah satu pilihan yang sesuai bagi murid dan pengajar untuk lebih mendalami materi dengan motivasi yang tinggi karena bentuknya yang berbeda dari yang sudah ada. Dari latar belakang di atas, maka peneliti menguji efektifitas atas bahan ajar yang telah dikembangkan dengan judul "Pengembangan Bahan Ajar Komik Pada Mata Pelajaran Bahasa Indonesia Materi Perjuangan Para Pahlawan".

Penelitian ini diharapkan dapat memberikan masukan atau pelengkap terhadap penelitian yang sudah ada untuk di jadikan bahan perbandingan sekaligus acuan dalam penelitian yang lain. Dengan melaksanakan telaah terhadap bahan-bahan pustaka yang berupa buku-buku, makalah, artikel di media massa dan lain sebagainya setidaknya sepanjang pengetahuan peneliti terhadap beberapa buku dan skripsi-skripsi sebelumnya yang mengungkap permasalahan di atas antara lain sebagai berikut.

Penelitian dan pengembangan atau Research and Development (R\&D) yang dilakukan oleh saudari Anis Rahmawati (136051893) dalam skripsinya yang berjudul "Pengembangan Media Pembelajaran Buku Bergambar Pada Mata Pelajaran Bahasa Indonesia Materi Menulis Puisi Kelas III Madrasah Ibtidaiyah Darussalamah Tajinan

\footnotetext{
2013, hlm. 2 .

5 Ika Lestari, Pengembangan Bahan Ajar Berbasis Kompetensi, Padang: Akademia Permata, ${ }^{6} \mathrm{http}: / /$ www.antaranews.com, dikutip Selasa, 13 Nopember 2018 20:59 WIB
} 
Malang”. Pada penelitian ini fokus kajian analisisnya membahas hal-hal yang berkaitan dengan pengembangan media ajar, hasil belajar khususnya di MI Darussalamah Tajinan Malang. Hasil pengembangan buku bergambar ini mencapai tingkat kevalidan 91\% yang menunjukan bahwa media buku bergambar efektif dan menarik. Hasil pre-test siswa mendapat nilai 63,33 dan hasil post-test siswa mencapai nilai 80,33 . Berdasarkan analisis menggunakan uji $\mathrm{T}$ menghasilkan $t_{\text {hitung }}$ 7,798 dan $t_{\text {tabel }} 2,069$ yang artinya terdapat perbedaan yang signifikan pada tingkat kemampuan menulis puisi siswa kelas 3 MI Darussalamah sebelum dan sesudah menggunakan media buku bergambar. ${ }^{7}$

Penelitian kedua, penelitian yang dilakukan Erlita Nugrahaningtyas dengan judul "Pengembangan Buku Cerita Bergambar sebagai Media Pembelajaran Pola Hidup Sehat untuk Anak Kelas 1 SD”. Hasil penelitian menunjukan penilaian guru kelas untuk buku cerita bergambar mendapat skor rata-rata 4,62 dengan kategori "sangat baik", sedangkan hasil penilaian dari dosen ahli mendapat nili rata-rata 4,21 dengan kategori "sangat baik". Hasil akhir kualitas buku cerita bergambar adalag 4,38 kategori "sangat baik" yang didapat dari rata-rata validasi dan rata-rata uji coba produk, hal tersebut menunjukan bahwa buku cerita bergambar tentang pola hidup sehat bagi anak kelas satu layak untuk digunakan sebagai bacaan siswa. ${ }^{8}$

Penelitian ketiga, penelitian Nova Triana Tarigan yang berjudul "Pengembangan Buku Cerita Bergambar untuk Meningkatkan Minat baca Siswa Kelas IV Sekolah Dasar" pada Jurnal Curere. Hasil penelitian ini menerangkan bahwa proses pembelajaran dengan buku cerita bergambar efektif meningkatkan minat siswa dalam membaca dengan skor -26,317 dengan probabilitas (sig) 0,000. Penelitian ini menunjukkan bahwa minat membaca dapat meningkat dengan buku cerita bergambar. Unsur-unsur buku cerita bergambar dapat meningkatkan minat siswa dalam membaca. ${ }^{9}$

Berdasarkan ketiga penelitian di atas, penelitian ini memiliki kesamaan penggunaan buku cerita bergambar dalam meningkatkan kualitas pembelajaran. Namun, penelitian ini memiliki perbedaan dalam pengemasan produk, produk disusun dalam

7 Anis Rahmawati "Pengembangan Media Pembelajaran Buku Bergambar Pada Mata Pelajaran Bahasa Indonesia Materi Menulis Puisi Kelas III Madrasah Ibtidaiyah Darussalamah Tajinan Malang” (Skripsi), Malang: Fakultas Tarbiyah dan Keguruan UIN Maulana Malik Ibrahim, 2016, hlm. 115

${ }^{8}$ Erlita Nugrahaningtyas "Pengembangan Buku Cerita Bergambar sebagai Media Pembelajaran Pola Hidup Sehat untuk Anak Kelas 1 SD” (Skripsi), Yogyakarta: Fakultas Keguruan dan Ilmu Pendidikan, Universitas Sanata Dharma, 2018, hlm. 99

${ }^{9}$ Nova Triana Tarigan "Pengembangan Buku Cerita Bergambar untuk Meningkatkan minat baca Siswa Kelas IV Sekolah Dasar” Jurnal Curere / Vol.02 / No. 02 / Oktober 2018 hlm. 150 
bentuk komik sedangkan penelitian terdahulu buku hanya disusun dalam bentuk cerita bergambar biasa. Penelitian terdahulu menjadi dasar bahwa pengemasan produk yang lebih menarik adalah point untuk bisa meningkatkan kualitas pembelajaran.

Kemampuan guru dalam merancang ataupun menyusun bahan ajar menjadi hal yang sangat berperan dalam menentukan keberhasilan proses belajar dan pembelajaran melalui sebuah bahan ajar. Bahan ajar tidak saja memuat materi tentang pengetahuan tetapi juga berisi tentang keterampilan dan sikap yang perlu dipelajari siswa untuk mencapai standar kompetensi yang telah ditentukan pemerintah ${ }^{10}$. Jenis bahan ajar, model, dan karakteristik bahan ajar yang akan digunakan sebagai alat belajar dan pembelajaran haruslah sesuai dengan kondisi murid. Pemilihan ini sangat penting mengingat terus berkembangnya pendidikan di Indonesia agar selalu inovatif dalam melaksanakan pembelajaran di sekolah.

Bahan ajar mempunyai struktur dan urutan yang sistematis, menjelaskan tujuan instruksional yang akan dicapai, memotivasi peserta didik untuk belajar, mengantisipasi kesukaran belajar peserta didik sehingga menyediakan bimbingan bagi peserta didik untuk mempelajari bahan tersebut, memberikan latihan yang banyak, menyediakan rangkuman, dan secara umum berorientasi pada peserta didik secara individual (learner oriented). Biasanya, bahan ajar bersifat mandiri, artinya dapat dipelajari oleh peserta didik secara mandiri karena sistematis dan lengkap. Beberapa hal mengenai bahan ajar akan dijelaskan sebagai berikut: ${ }^{11}$

1) Karakteristik Bahan Ajar

Sesuai dengan pedoman penulisan modul yang dikeluarkan oleh Direktorat Guruan Menengah Kejuruan Direktorat Jendral Pendidikan Dasar dan Menengah Departeman Pendidikan Nasional Tahun 2003, bahan ajar memiliki beberapa karakteristik, yaitu:

2) Self instructional, yaitu bahan ajar dapat membuat siswa mampu membelajarkan diri sendiri dengan bahan ajar yang dikembangkan. Untuk memenuhi karakter self instructional, maka di dalam bahan ajar harus terdapat tujuan yang dirumuskan dengan jelas, baik tujuan akhir maupun tujuan antara.

\footnotetext{
${ }^{10}$ Ika Lestari, Pengembangan Bahan Ajar Berbasis Kompetensi, Padang: Akademia Permata, 2013, hlm. 1.

${ }^{11}$ Ika Lestari, Pengembangan Bahan Ajar Berbasis Kompetensi, Padang: Akademia Permata, 2013, hlm. 12-9
} 
3) Self contained, yaitu seluruh materi pelajaran dari satu unit kompetensi atau subkompetensi yang dipelajari terdapat di dalam satu bahan ajar secara utuh

4) Stand alone (berdiri sendiri) yatu bahan ajar yang dikembangkan tidak tergantung pada bahan ajar lain atau tidak harus digunakan bersama-sama dengan bahan ajar lain

5) Adaptive, yaitu bahan ajar hendaknya memiliki daya adaptif yang tinggi terhadap perkembangan ilmu dan teknologi

6) User friendly, yaitu setiap instruksi dan paparan informasi yang tampil bersifat membantu dan bersahabat dengan pemakainya, termasuk kemudahan pemakai dalam merespon dan mengakses sesuai keinginan

7) Jenis-jenis Bahan Ajar

Bahan ajar dalam pendidikan dibedakan menjadi:

a) Modul, yaitu bahan ajar yang ditulis dengan tujuan agar siswa dapat belajar secara mandiri tanpa atau dengan bimbingan guru, oleh karena itu, modul harus berisi tentang petunjuk belajar, kompetensi yang akan dicapai, isi materi pelajaran, informasi pendukung, latihan soal, petunjuk kerja, evaluasi, dan balikan terhadap hasil evaluasi

b) Lembar Kerja Siswa (LKS), yakni materi ajar yang sudah dikemas sedemikian rupa sehingga siswa diharapkan dapat materi ajar tersebut secara mandiri

c) Bahan ajar noncetak meliputi: bahan ajar dengar (audio) seperti radio, piringan hitan, dan compact disc audio; bahan ajar pandang dengar (audio visual) seperti video compact disc dan film; dan bahan ajar multimedia interaktif (interactive teaching material) seperti CAI (Computer Assisted Instruction), compact disc (CD) multimedia pembelajaran interaktif, dan bahan ajar berbasis web (web based learning materials).

Komik dapat didefinisikan sebagai suatu bentuk kartun yang mengungkapkan karakter dan memerankan suatu cerita dalam urutan yang erat dihubungkan dengan gambar dan dirancang untuk memberikan hiburan kepada para pembaca. ${ }^{12}$ Komik memusatkan perhatian di sekitar rakyat. Cerita-ceritanya mengenai diri pribadi sehingga para pembaca dapat segera mengidentifikasikan dirinya melalui perasaan serta tindakan dari perwatakan-perwatakan tokoh utamanya.

\footnotetext{
12 Nana Sudjana dan Ahmad Rivai, MEDIA PENGAJARAN: Penggunaan dan Pembuatannya, Bandung: Sinar Baru, 1990, hlm. 64.
} 
Cerita-ceritanya ringkas dan menarik perhatian, dilengakapi dengan aksi, bahkan dalam lembaran surat kabar, dan buku-buku, komik dibuat lebih hidup, serta diolah dengan pemakaian warna-warna utama secara bebas. Suatu analisis terhadap bahasa komik oleh Thorndike menunjukkan ada segi yang menarik. Dapat diketahui bahwa anak yang membaca sebuah buku komik setiap bulan, hampir 2 kali banyaknya kata-kata yang dapat dibaca sama dengan yang terdapat pada buku-buku bacaan yang dibacanya setiap tahun terus menerus. Thorndike berkesimpulan bahwa baik jumlah maupun perwatakan dari segi perbendaharaan kata melengkapi secara praktis dalam membaca untuk para pembaca muda. Peranan pokok dari buku komik dalam pengajaran adalah kemampuannya dalam menciptakan minat para siswa. Penggunaan komik dalam pengajaran sebaiknya dipadu dengan metode mengajar, sehingga komik akan dapat menjadi alat pengajaran yang efektif. ${ }^{13}$ Meskipun komik merupakan salah satu sarana efektif dalam menambah motivasi belajar, guru juga harus memperhatikan sisi negatif dari komik sehingga dapat ada perlakuan yang dapat mengatasi sisi negatif.

Pembelajaran bahasa Indonesia diberikan pada seluruh jenjang pendidikan dari tingkat sekolah dasar hingga perguruan tinggi. Pembelajaran bahasa Indonesia pada masing-masing jenjang memiliki tujuan yang berbeda satu sama lain. Perbedaan ini bukan sekedar dalam hal materi melainkan juga berkenaan dengan gradiasi keterampilan yang harus dimiliki. Berdasarkan gradiasinya ini sebenarnya arah pembelajaran bahasa Indonesia pada semua jenjang pendidikan adalah sama yakni mencapai tujuan pembelajaran sebagaimana tercantum dalam kurikulum yang berlaku. ${ }^{14}$ Dalam perumusan tujuan pembelajaran Bahasa Indonesia semua jenjang pendidikan mengarah pada perkembangan aspek keterampilan membaca, menulis, mendengarkan dan berbicara dengan baik dan benar.

Materi Bahasa Indonesia yang menjadi fokus dalam komik ini adalah materi bahasa Indonesia di kelas 4 tentang tema kepahlawanan Pangeran Diponegoro yaitu:

a) Profil Pangeran Diponegoro

Dipanegara atau dikenal dengan gelar Pangeran Dipanegara (Bahasa Jawa: Diponegoro) (lahir di Yogyakarta, 11 November 1785 - meninggal di Makassar,

\footnotetext{
${ }^{13}$ Nana Sudjana dan Ahmad Rivai, MEDIA PENGAJARAN: Penggunaan dan Pembuatannya, Bandung: Sinar Baru, 1990, hlm. 64-68.

${ }^{14}$ Yunus Abidin, op.cit., hlm. 14
} 
Sulawesi Selatan, 8 Januari 1855 pada umur 69 tahun) adalah salah seorang pahlawan nasional Republik Indonesia.

Dipanegara adalah putra sulung Hamengkubuwono III, seorang raja Mataram di Yogyakarta. Menyadari kedudukannya sebagai putra seorang selir, Dipanegara menolak keinginan ayahnya, Sultan hamengkubuwono III, untuk mengangkatnya menjadi raja. Ia menolak mengingat ibunya bukanlah permaisuri.

b) Sikap Pangeran Diponegoro

Sikap Dipanegara yang menentang Belanda secara terbuka, mendapat simpati dan dukungan rakyat. Atas saran Pangeran Mangkubumi, pamannya, Dipanegara menyingkir dari Tegalrejo, dan membuat markas di sebuah goa yang bernama Goa Selarong. Saat itu, Dipanegara menyatakan bahwa perlawanannya adalah perang sabil, perlawanan menghadapi kaum kafir. Semangat "perang sabil" yang dikobarkan Dipanegara membawa pengaruh luas hingga ke wilayah Pacitan dan Kedu. Salah seorang tokoh agama di Surakarta, Kyai Maja, ikut bergabung dengan pasukan Dipanegara di Goa Selarong.

c) Perjuangan Pangeran Diponegoro

Perang Diponegoro berawal ketika pihak Belanda memasang patok di tanah milik Dipanegara di desa Tegalrejo. Saat itu, beliau memang sudah muak dengan kelakuan Belanda yang tidak menghargai adat istiadat setempat dan sangat mengeksploitasi rakyat dengan pembebanan pajak.

Serangan-serangan besar rakyat pribumi selalu dilaksanakan pada bulan-bulan penghujan; para senopati menyadari sekali untuk bekerjasama dengan alam sebagai "senjata" tak terkalahkan. Dengan penuh kegigihan akhirnya Pangeran dan Pasukan Diponegoro mampu mengalahkan penjajah.

Produk yang dikembangkan dalam penelitian ini berupa bahan ajar komik pada mata pelajaran Bahasa Indonesia materi Kepahlawanan di Sekolah Dasar. Adapun spesifikasi produk yang dikembangkan adalah sebagai berikut:

1. Produk yang akan dikembangkan adalah komik.

2. Produk komik didesain dengan gambar yang menarik dan unik

3. Komik dilengkapi dengan teks untuk mempermudah pemahaman bagi pembaca khususnya para siswa

4. Produk komik dibuat dengan penuh warna 
5. Produk komik dibuat seindah mungkin dengan dipadukan dengan gradasi warna sehingga menarik bagi peserta didik

6. Ketebalan kertas cover komik didesain lebih tebal daripada isi

7. Komik terdiri dari cover, pengantar, isi dan penutup.

\section{B. METODE PENELITIAN}

Pendekatan penelitian yang digunakan adalah pendekatan kuantitatif. Metode penelitian yang digunakan adalah penelitian pengembangan. Desain penelitian yang digunakan adalah desain penelitian dan pengembangan, yang memuat sepuluh tahap pelaksanaan mengacu pada teori Borg dan Gall. Teknik analisis data yang digunakan dalam uji keefektifan menggunakan uji-t aplikasi SPSS 21 untuk mengetahui perbedaan hasil pemahaman siswa soal awal (pre test) dan setelah penyampaian materi (post test)menggunakan komik dengan taraf signifikan 5\%.

Langkah pembuatan bahan ajar komik pada pokok bahasan materi kepahlawanan sebagai berikut:

1. Menyiapkan sumber atau buku referensi tentang materi kepahlawanan sebagai materi pokok yang akan diajarkan kepada siswa

2. Melakukan identifikasi terhadap Kompetensi Inti, kompetensi dasar, indikator, dan strategi belajar

3. Merancang format pembuatan bahan ajar komik

4. Mengembangkan bahan ajar komik dengan merubah warna, dengan merubah bentuk warna yang dahulu telah peneliti kembangkan, diharapkan dapat menarik perhatian anak untuk memahami tema kepahlawanan

5. Membuat produk akhir yaitu dengan mengemas sedemikian rupa

6. Menyebarluaskan dan mengimplikasikan produk

Jenis data dalam penelitian ini adalah data kualitatif dan kuantitatif. Teknik pengumpulan data yang digunakan tes dan nontes. Instrumen yang digunakan angket analisis kebutuhan, pedoman wawancara, angket validasi, lembar observasi, dan pre-test post-test. Teknik analisis data yang digunakan untuk uji keefektifan Komik pada Materi Perjuangan Para Pahlawan menggunakan uji-t aplikasi SPSS 21 untuk mengetahui perbedaan hasil pemahaman siswa soal awal (pre test) dan setelah penyampaian materi (post test) menggunakan komik dengan taraf signifikan 5\%. Data yang diperoleh 
melalui instrumen penilaian pada saat ujicoba di analisis dengan menggunakan statistic deskriptif kualitatif dan kuantitaif, analisis ini dimaksudkan untuk menggambarkan karakteristik data pada masing-masing variabel, hasil analisi data digunakan sebagai dasar untuk merevisi produk media yang dikembangkan.

\section{HASIL DAN PEMBAHASAN}

Hasil penelitian diperoleh dari para ahli ketika pengujian dan dari siswa ketika kegiatan implementasi. Pengujian produk diperoleh hasil melalui angket oleh ahli materi, ahli media dan siswa. Berikut adalah hasil dari penilaian ahli materi.

Tabel 1. Hasil Validasi Ahli Materi

\begin{tabular}{cccccc}
\hline No & $\begin{array}{c}\text { Aspek yang } \\
\text { Dinilai }\end{array}$ & Nilai & $\begin{array}{c}\text { Nilai } \\
\text { Maksimal }\end{array}$ & Presentase & Keterangan \\
1 & Materi & 78 & 100 & $78 \%$ & Baik \\
\hline
\end{tabular}

Berdasarkan hasil angket validasi di atas diperoleh hasil total 78 dari total nilai maksimum 100 Dapat disimpulkan bahwa bahan ajar komik materi perjuangan para pahlawan dalam kategori baik.

Hasil penilaian dari ahli media sebagai berikut.

Tabel 2. Hasil Validasi Ahli Media

\begin{tabular}{cccccc}
\hline No & $\begin{array}{c}\text { Aspek yang } \\
\text { Dinilai }\end{array}$ & Nilai & $\begin{array}{c}\text { Nilai } \\
\text { Maksimal }\end{array}$ & Presentase & Keterangan \\
\hline 1 & Materi/Isi & 19 & 25 & $76,00 \%$ & Baik \\
\hline 2 & Penyajian & 46 & 60 & $76,66 \%$ & Baik \\
\hline 3 & Tampilan & 12 & 15 & $80,00 \%$ & Baik \\
\hline
\end{tabular}




\section{Grafik 1. Hasil Validasi Ahli Media}

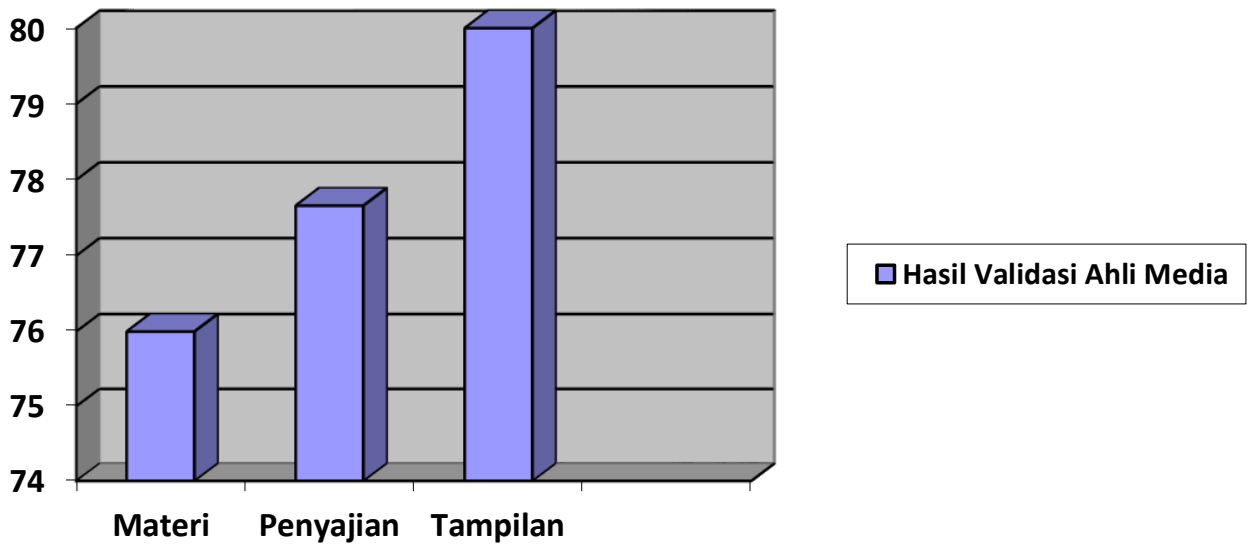

Melalui data di atas dapat diartikan bahwa ahli media menyebutkan dari aspek materi/isi komik memiliki kategori baik dengan 76,00 \%. Dari aspek penyajian dengan $76,66 \%$ berkategori baik. Sedangkan aspek tampilan mengenai kualitas teknis dan kefektifan dinyatakan baik dengan $80,00 \%$.

Kesimpulan dari data diatas bahwa bahan ajar komik pada mata pelajaran Bahasa Indonesia materi perjuangan para pahlawan dikatakan baik dari segi kualitas media. Aspek penyajian data dinyatakan baik dan aspek tampilan dinyatakan baik. Sehingga bahan ajar komik materi perjuangan para pahlawan dinyatakan layak untuk dapat diterapkan dalam proses pembalajaran.

Menguji keefektifan bahan ajar komik pada mata pelajaran Bahasa Indonesia materi perjuangan para pahlawan dilakukan dengan dua cara yaitu melalui tes pemahaman materi sebelum penggunaan bahan ajar komik serta setelah penggunaan bahan ajar komik. Berikut adalah grafik pre-test dan post-test. 


\section{Grafik 2. Hasil Pre Test dan Post Test}

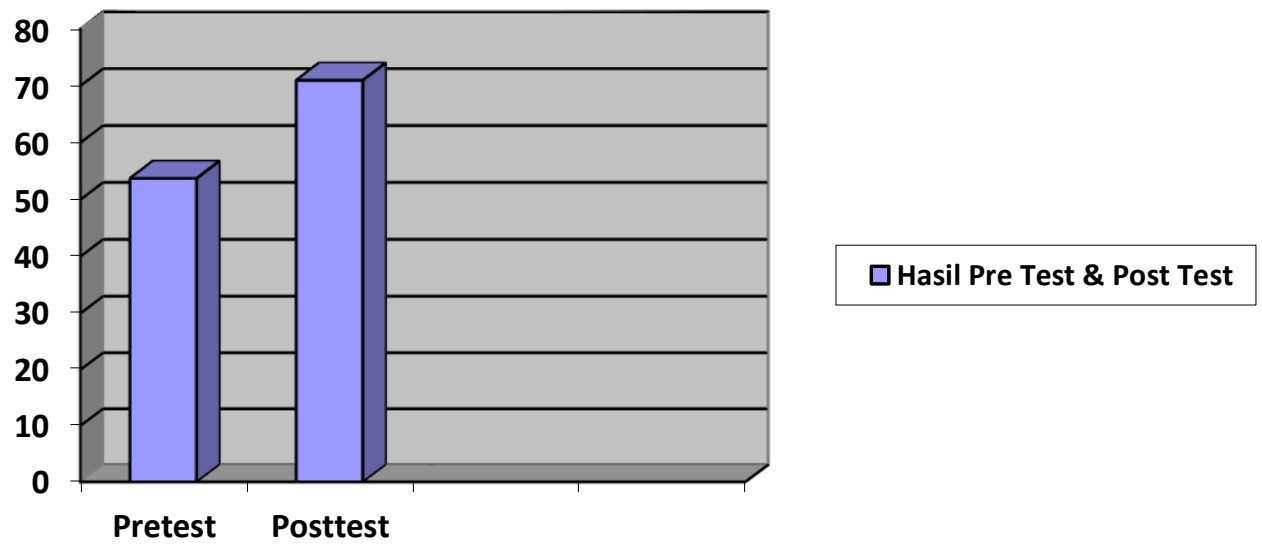

Grafik tersebut menerangkan bahwa adanya peningkatan nilai pada pre-test dan post-test. Untuk Menguji keefektifan pembelajaran digunakan uji t-satu sampel (uji pihak kanan). Hipotesis yang digunakan:

Ho: "Tidak ada perbedaan hasil belajar antara sebelum dan sesudah menggunakan bahan ajar komik pada kelas IV MI Tinjomoyo Semarang"

Ha : "Ada perbedaan hasil belajar antara sebelum dan sesudah menggunakan bahan ajar komik pada kelas IV MI Tinjomoyo Semarang

Dalam menguji keefektifan bahan ajar komik pembelajaran ini dilakukan dengan dua cara yaitu melalui tes pemahaman materi sebelum penggunaan bahan ajar komik serta setelah penggunaan bahan ajar komik mata pelajaran Bahasa Indonesia pokok bahasan perjuangan para pahlawan. Hasil perhitungan diperoleh pada $\alpha=5 \%$ dengan $\mathrm{dk}=22-1=21$ diperoleh $\mathrm{t}$ tabel $=2,119$. Didapat $\mathrm{t}$ hitung $=11,054 \geq$ ttabel $=2,119$. Karena $\mathrm{t}$ hitung $\geq$ ttabel maka hipotesis (Ha) diterima. Maka dapat disimpulkan ada peningkatan hasil belajar sesudah siswa menggunakan bahan ajar komik pada kelas IV MI Tinjomoyo dan karena hal tersebut bahan ajar dikatakan efektif. 
D. SIMPULAN

Dari hasil penelitian dapat disimpulkan bahwa bahan ajar komik pada mata pelajaran bahasa indonesia materi perjuangan para pahlawan efektif untuk digunakan, hal ini dibuktikan dengan besaran $t$ hitung $=11,054 \geq$ ttabel $=2,119$ dengan $\alpha=5 \%$ karena $t$ hitung $\geq$ ttabel maka hipotesis $(\mathrm{Ha})$ diterima. 


\section{DAFTAR PUSTAKA}

Abidin, Abidin, Pembelajaran Bahasa Berbasis Pendidikan Karakter, Bandung: PT. Refika Aditama, 2012

Arifin, Zainal, Penelitian Pendidikan. Bandung: PT. Remaja Rosdakarya, 2014

Arikunto, Suharsimi. 2013. Prosedur Penelitian Suatu Pendekatan Praktik, Cet. 15. Jakarta : PT. Rineka Cipta

Lestari, Ika., Pengembangan Bahan Ajar Berbasis Kompetensi, Padang: Akademia Permata, 2013

Nurgiyantoro, Burhan., Sastra Anak Pengantar Pemahaman Dunia Anak. Yogyakarta: Gadjah Mada University Press, 2010.

Nugrahaningtyas, Erlita, Pengembangan Buku Cerita Bergambar sebagai Media Pembelajaran Pola Hidup Sehat untuk Anak Kelas 1 SD. (Skripsi), Yogyakarta: Fakultas Keguruan dan Ilmu Pendidikan, Universitas Sanata Dharma., 2018

Tarigan, Nova Triana, Pengembangan Buku Cerita Bergambar untuk Meningkatkan minat baca Siswa Kelas IV Sekolah Dasar. Jurnal Curere Vol. 02 No. 02 , 2018

Sudjana, Sudjana dan Ahmad Rivai, Media Pengajaran: Penggunaan dan Pembuatannya, Bandung: Sinar Baru, 1990.

Zulela, Pembelajaran Bahasa Indonesia Apresiasi Sastra di Sekolah Dasar, Bandung: PT. Remaja Rosdakarya, 2013

http://www.antaranews.com, dikutip Selasa, 13 Nopember 2018 20:59 WIB 